\title{
Il disegno della danza. Notazione e controllo dello spazio performativo
}

\author{
Massimiliano Ciammaichella
}

Abstract

Per la disciplina della danza il disegno ha sempre assunto un ruolo centrale nella progettazione della coreografia, anche se la storia dimostra come nel Novecento la rappresentazione orientata alla semantizzazione di una pratica, immediatamente comprensibile, sembri essere sostituita da codici grafici e combinazioni numeriche che ne astraggono il significato.

Oggetto di indagine primaria sono proprio i sistemi notazionali della danza, diffusi a partire dalla fine del Seicento per opera di diversi coreografi, autori di trattati illustrati, che documentano nella sintesi bidimensionale del supporto cartaceo la complessità delle traiettorie spazio-temporali, le posture e i movimenti degli arti coinvolti nell'azione coreica da interpretare. Spesso sono proprio i ballerini a prendere le distanze da queste forme di trascrizione, perché non sono in grado di leggerle e tradurle. Pertanto, il paper indaga le teorie e i metodi di trasposizione grafica della notazione, per comprenderne le logiche di progettazione, evidenziando come tutti i casi studio analizzati siano originati dallo studio del corpo e dei suoi cinematismi. Ma le tecnologie digitali favoriscono inediti paradigmi della rappresentazione, dimostrando come le esperienze contemporanee abbattano proprio quelle distanze di cui si è fatto cenno, diventando il banco di prova di sperimentazioni nelle quali il corpo incarnato e il suo clone digitale intrattengono un dialogo aperto con i sistemi notazionali della danza.

Parole chiave

corpo umano, notazione, coreografia, animazione 3D, cattura del movimento.

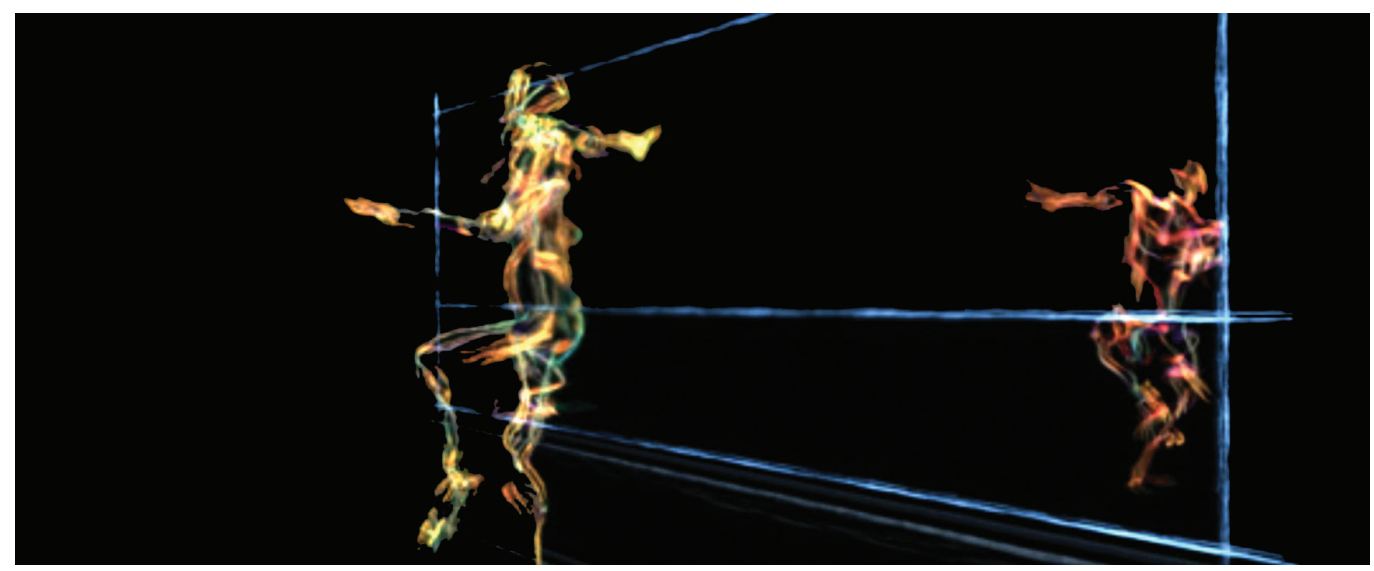


I linguaggi della danza, intesa come disciplina che prende le distanze dalla libera espressione del corpo, per sottoporlo alle austere regole della coreografia progettata, si sono affidati nel corso dei secoli alla ricerca di forme di trascrizione segnica unificanti, fatte di codici grafici atti a tradurre il perfettibile movimento nell'esibizione perimetrata dallo spazio di azione scenica.

Storicamente la scelta di normare la gestualità fisica, la postura e le traiettorie di una riproducibile mozione attivata dalla musica, si è originata nella Francia del Re Sole, colui che nel |66| fonda l'Académie Royale de Danse e la fa dirigere al maestro di danza di corte Pierre Beauchamp, tra il 1680 e il 1687.

In questo contesto il coreografo sperimenta e perfeziona le cinque posizioni base della danza classica, cogliendo anche l'invito di Luigi XIV a sviluppare un sistema di notazione capace di dialogare con la trascrizione dello spartito musicale. Così, il suo allievo Raoul Auger Feuillet nel 1700 pubblica un trattato di coreografia, manifestando per la prima volta nel titolo la volontà di esprimere il balletto nei termini di carattere e figura dimostrativa [Feuillet 1700]. Nel rispetto della declaratoria, la messa a sistema di un linguaggio fondato su un lessico visivo si esplicita nella costruzione di un alfabeto di posture che si confrontano con lo spazio bidimensionale, tracciato dalle geometrie curve delle azioni calibrate da una fisicità che lo misura e lo ridisegna, attraverso il suo movimento.

Si parte dalla posizione del corpo, schematizzato da un segno rettilineo raccordato da un arco di circonferenza che ne indica l'orientamento, poi si prosegue con la graficizzazione delle cinque posizioni dei piedi, stilizzati da rette e circoli che identificano l'appoggio del tallone, per giungere alla definizione delle traiettorie, rettilinee o curve, che vengono interrotte da uno o più segmenti determinanti le specifiche del passo da compiere: piegato; elevato; semplicemente saltato oppure cabriole, su un solo piede toccato in aria dall'altro prima di raggiungere il suolo all'unisono; cadente e scivolato (fig. I).

Questo sistema di notazione è stato ampiamente utilizzato anche in altri paesi e forse ci offre l'unica via per risalire allinterpretazione delle originali coreografie storiche, in linea con l'idea di Beauchamp di costruire un metodo per registrare i balletti, di corte e dell'Opera, in modo tale che potessero essere appresi autonomamente, senza l'ausilio di un maestro
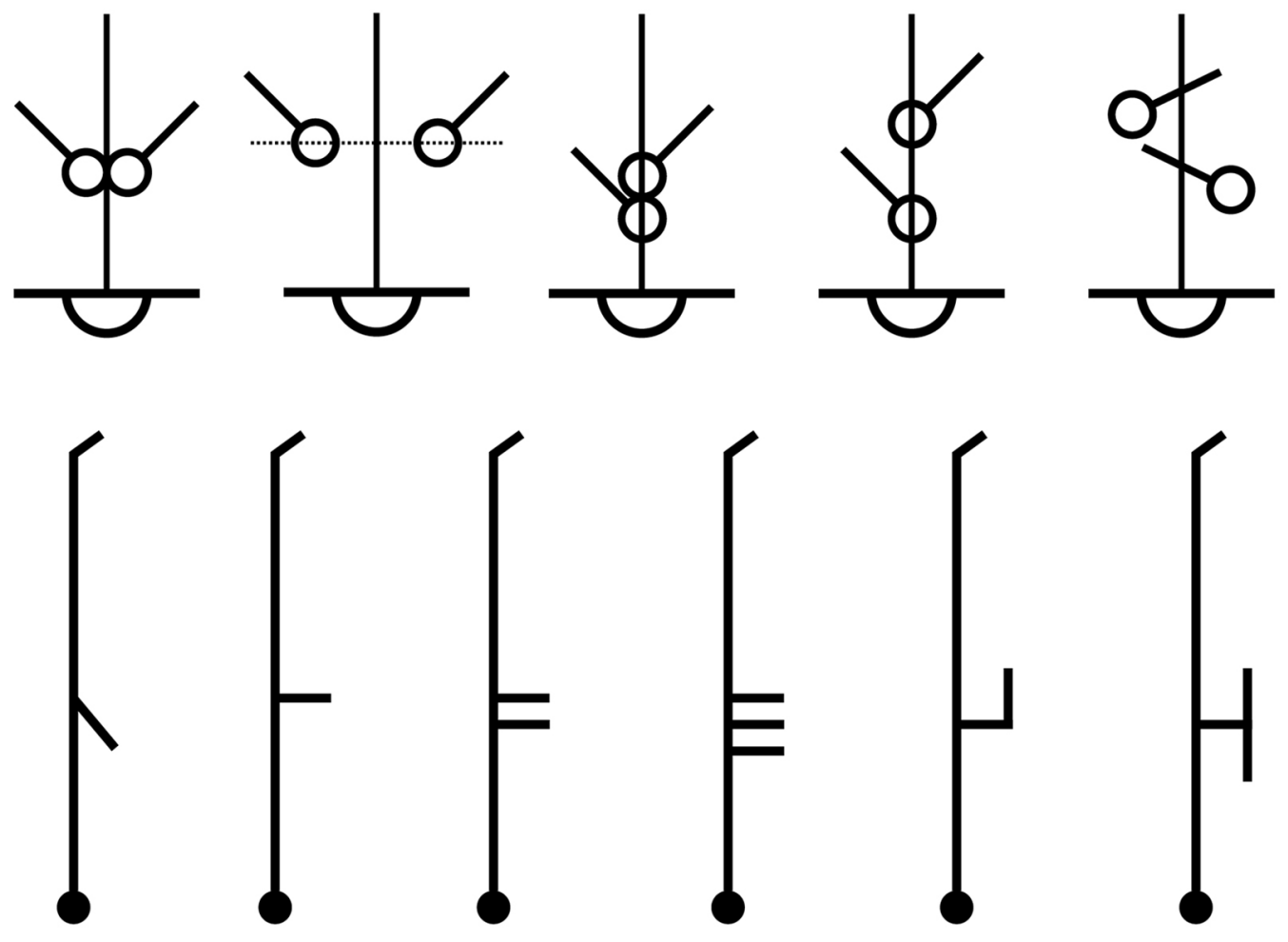
[Pierce 1998, p. 290]. Ma i limiti delle illustrazioni risiedono nella distribuzione piana di un complesso insieme di simboli che privilegia la proiezione icnografica, senza confrontarsi con la reale scala degli spostamenti dei ballerini nel modulare le sequenze. Allora la volontà di rendere la rappresentazione soggettiva - nelle pubblicazioni degli anni Venti e Trenta del Settecento -, si confronta con le prospettive centrali di spazi neutri abitati da corpi, che rendono oggettiva l'enfasi di una simmetria imposta dalle danze di coppia, come ad esempio si evince dalle incisioni raccolte nei volumi di Anthony L'Abbé e Kellom Tomlinson [L'Abbé I 725 ca.; Tomlinson 1735].

Queste immagini storicizzano movenze e costumi ascrivibili al periodo in cui sono state prodotte. Pongono l'accento sulla postura delle gambe e dell'appoggio del piede, nella comunicazione grafica di una espressione coreutica decisamente funzionale all'estetica tardobarocca, tutta concentrata sullimportanza del passo da compiere e meno sulle articolazioni delle braccia, spesso aperte in avanti per evidenziare le pose delle mani che non superano mai l'altezza delle spalle (figg. 2, 3).

Fig. 2. Anthony L'Abbé, Chacone [L'Abbé A. I 725 ca., p. 22].

Fig. 3. Kellom Tomlinson, Passacaille Tomlinson K I735, p. 200].
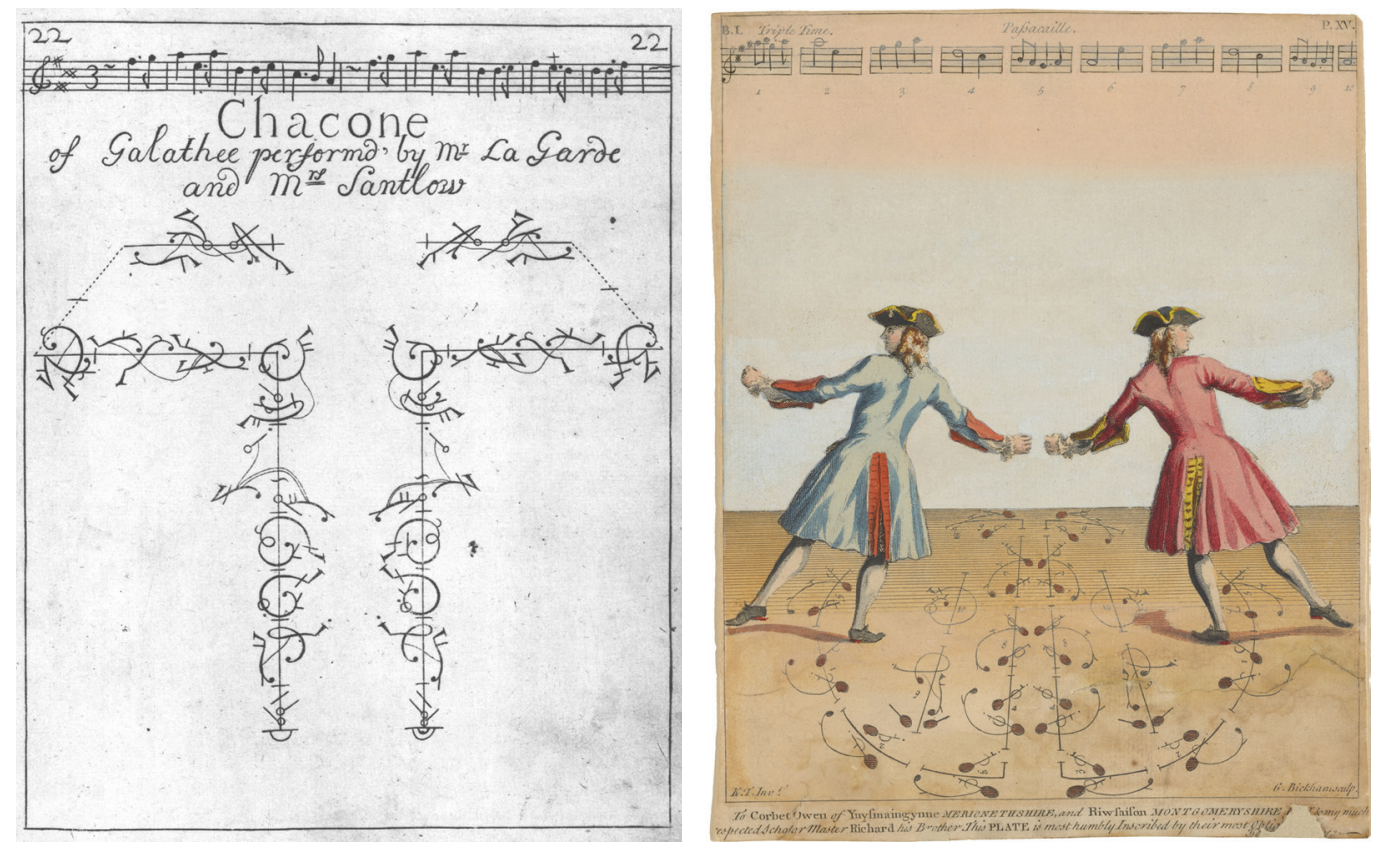

Nell'evoluzione degli stili, la volontà dei coreografi di trovare una specifica ed efficace comunicazione del corretto movimento danzato, in immagini utili a renderlo riproducibile, diventa una necessità. Lo dimostrano le continue proposte di sistemi notazionali che si moltiplicano nell'Ottocento, razionalizzando un complesso di informazioni quali il tempo, lo spazio e l'azione fisica, su un supporto bidimensionale che a partire da qui si concentra sulla rappresentazione ortografica.

Si mostra il disegno del corpo, seppur nei tratti essenziali della sua riconoscibilità, ma ciò probabilmente è dovuto all'evoluzione di costumi di scena sempre più leggeri e aderenti che ne esaltano le fattezze [Hutchinson Guest 1984, p. 68]. Così, nella 'stenocoreografia' di Arthur Saint-Léon, del I852, una gamma di segni - che classificano le azioni della parte superiore del busto, scindendole da quella inferiore - offre un ampio ventaglio di combinazioni, la cui interpretazione, paradossalmente, è rivolta al pubblico che osserva frontalmente la scena e non al danzatore che ne deve invertire la lettura, disposta su un 'pentagramma coreografico' ordinato dalla descrizione della tecnica e dalle traiettorie del moto spaziale [Saint-Léon 1852]. 
II metodo proposto da Saint-Léon viene semplificato da Friederich Albert Zorn, in Grammatik der Tanzkunst del I 887 [Zorn I887].

Le raffigurazioni dell'atlante accompagnano il volume spiegando le logiche di una eidografica sintesi antropomorfica, dedotta dalle geometrie dei limiti motori imposti dagli arti, nelle sequenze riprese frontalmente e di profilo, così da cadenzare i tempi musicali delle singole configurazioni coreografiche, tutte anticipate da una sintetica schematizzazione prospettica dell'intero disegno cinetico, tracciato sulla superficie del palcoscenico (figg. 4, 5).
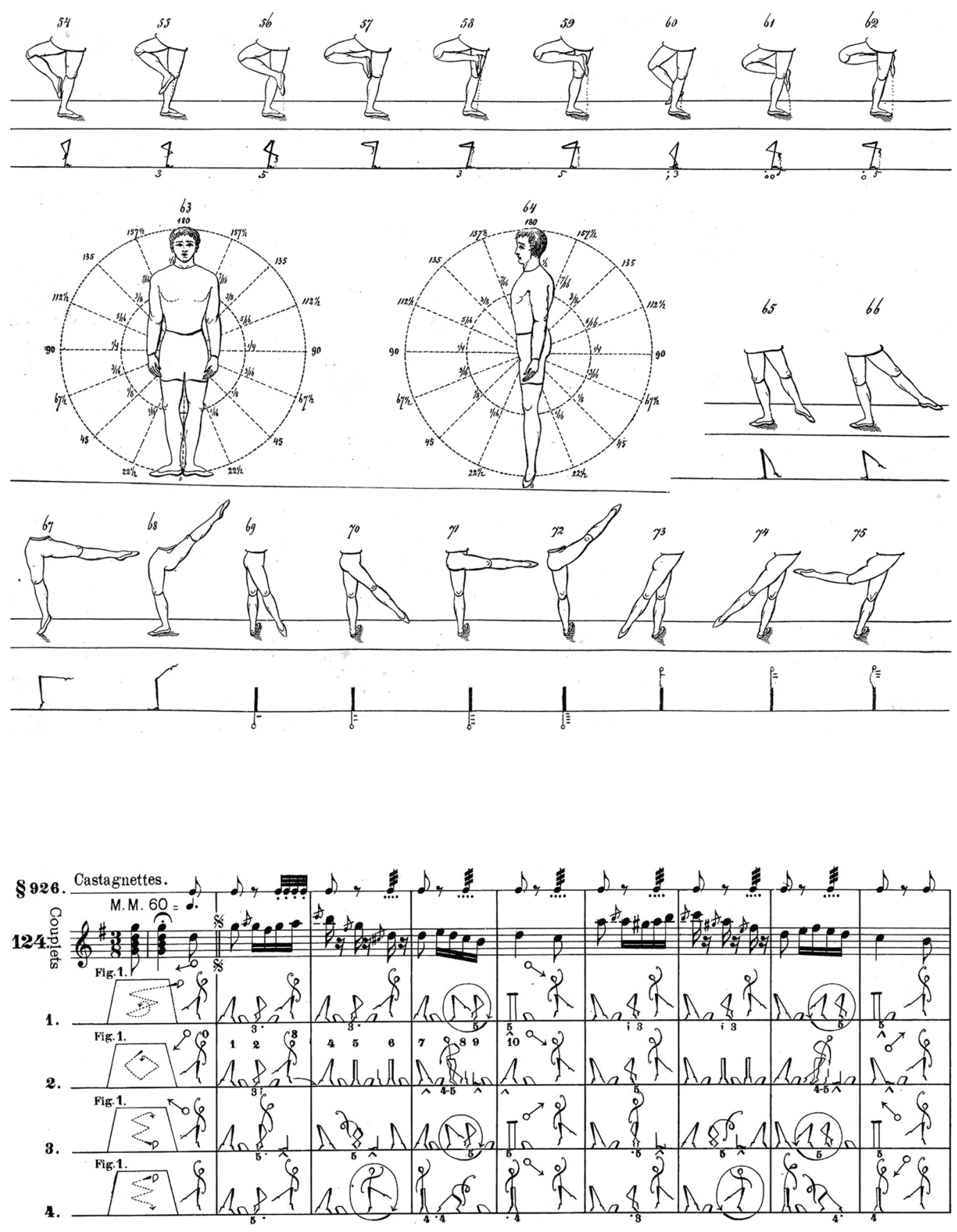
Malgrado le sperimentazioni ottocentesche arrivino a una forma di intelligibilità del corpo disegnato, che attiva le sue performanti mozioni registrate da sequenze di fotogrammi posturali, contrariamente, le proposte novecentesche sembrano annullarne la presenza.

II corpo umano subisce la privazione della sua immanente riconoscibilità, perché sostituito dall'apparente funzionalità costruttiva di complessi glossari visivi che hanno la pretesa di descrivere l'ampio ventaglio di azioni motorie possibili.

In generale, secondo Edward Tufte, questa spasmodica urgenza di costruire un linguaggio grafico universalizzante l'espressione coreutica - indipendentemente dai metodi scelti per la sua rappresentativa descrizione -, piuttosto che operare una simbiosi fra scientificità e narrazione ne ha messo in crisi l'inevitabile relazione [Tufte 1990, pp. II8, I|9].

In realtà, riuscire a sintetizzare, nella bidimensionalità di un quadro sinottico, il complesso di informazioni necessarie a comprendere l'insieme dei movimenti da compiere, in funzione del tempo e dello spazio di azione, significa confrontarsi con modelli di rappresentazione orientati all'astrazione di geometrie piane, traducibili in codici grafici che comunque vanno appresi ancor prima di essere letti e interpretati.

Sistemi notazionali tra i più accreditati, e ancora oggi utilizzati, come la 'cinetografia' [I] teorizzata da Rudolf Laban nel 1928, nascono dall'osservazione diretta delle combinazioni posturali offerte dal corpo di un danzatore, che le attua all'interno di una struttura icosaedrica, per estrapolare dalla pratica empirica il modello teorico allinterno del quale tracciare le geografie motorie. Laban lo definisce nei termini di una 'kinesfera' la cui superficie viene toccata dagli arti in punti che determinano i codici visivi necessari alla composizione [Laban 1928]. Sono rettangoli, trapezi e triangoli - con tre diverse campiture che simboleggiano l'altezza degli arti coinvolti - a posizionarsi in un rigoroso apparato visivo leggibile dal basso verso l'alto, tripartito da fasce verticali che inquadrano le azioni delle estremità laterali e centrali del corpo (fig. 6).

Fig. 6. Massimiliano Ciammaichella, ricostruzione della 'kinesfera' e dei simbo grafici del sistema notazionale proposto ne 1928 da Rudolf Laban, 2020.
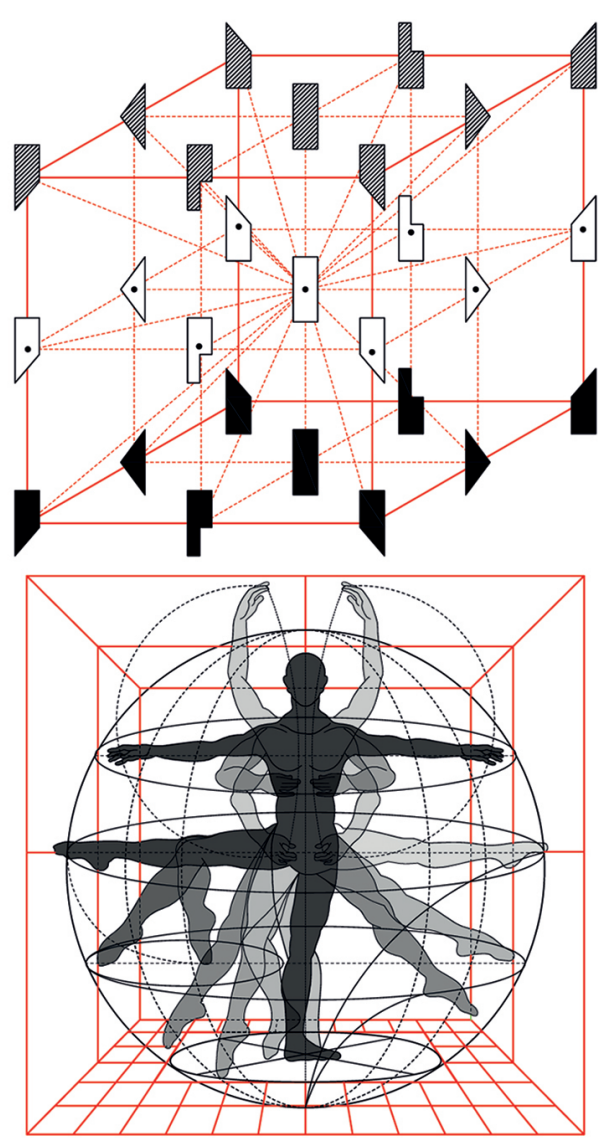
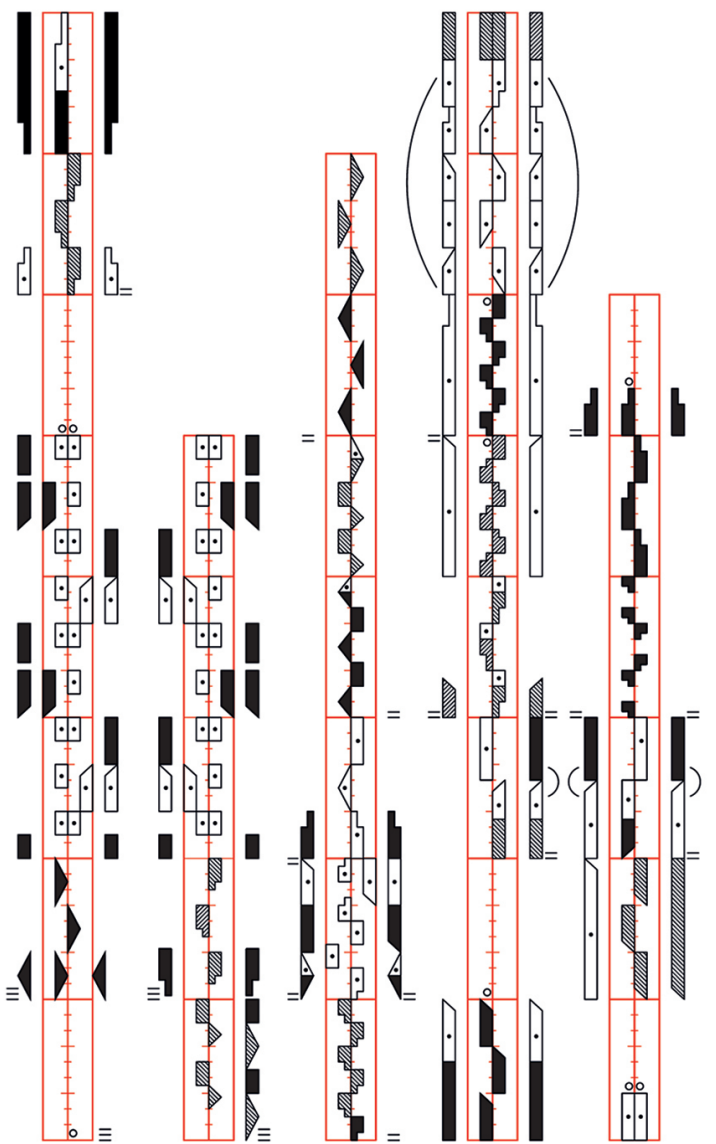
Fig. 7. Avraham Wachman II sistema di riferimento principale e privato, 1950 ca. Inchiostro e collage su carta, $20 \times 20 \mathrm{~cm}$. (Per gentile concessione della Noa Eshkol Foundation for Movement Notation)

Fig. 8. John G. Harries, Movimento conico, 1950 ca. Inchiostro e collage su carta, $30,5 \times 25 \mathrm{~cm}$. Per gentile concessione della

Fig. 9. John G. Harries, Analisi di una posizione de corpo, con annotazione sula cagina manoscritta 1950 I950 ca. Inchiostro su . entile concession della Noa Eshko Movement Notation).

Fig. 10. Avraham Wachman, Analisi di una posizione di tutto it corpo, illustrato con figura a bastoncino, sistema di riferimento e pagin manoscritto 1950 ca. Inchiostro e collage su pergamena, $24 x$ $315 \mathrm{~cm}$ (Per $24 x$ $31,5 \mathrm{~cm}$. (Per gentile concessione della Noa Movement Notation).

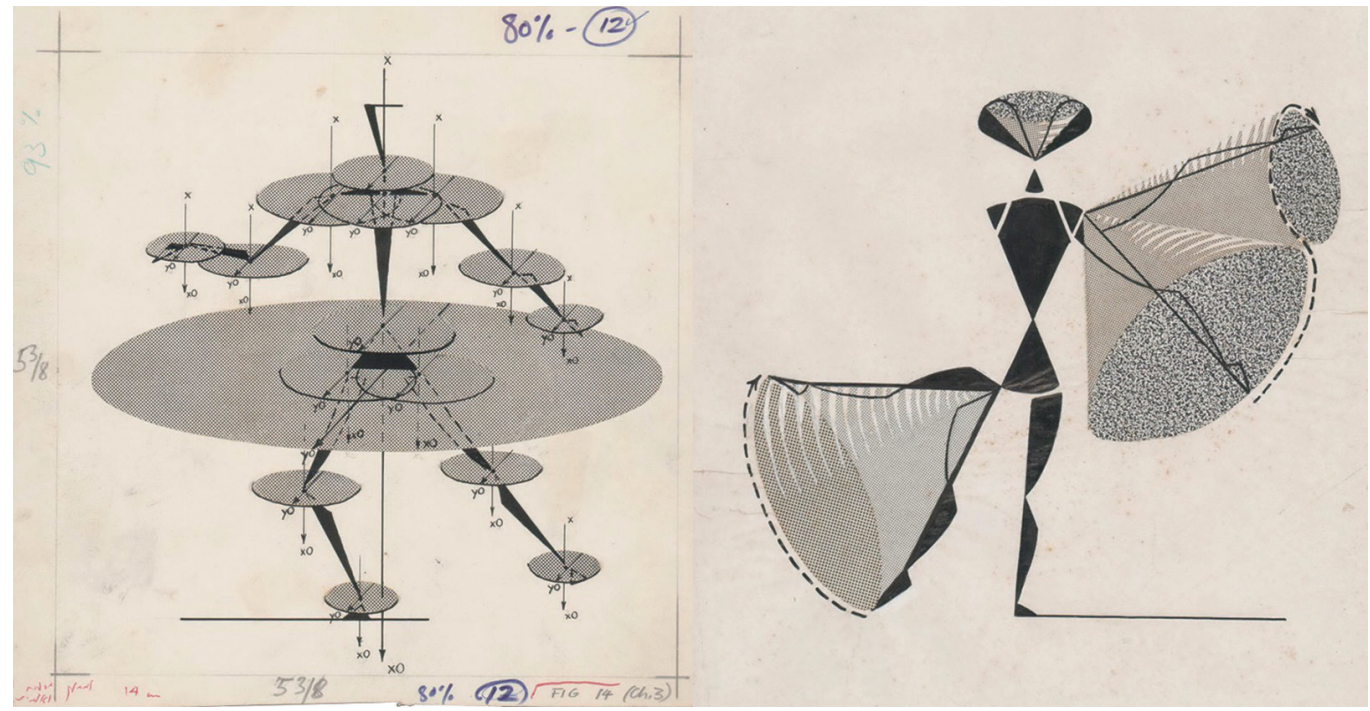

II metodo di Laban presenta analogie con quello proposto da Feuillet, tuttavia non permette di riconoscere immediatamente le direzioni del percorso spaziale da compiere, per le quali è necessario ricorrere ad ulteriori simbologie grafiche [Pontremoli 2004, pp. 60, 6I ].

La 'coreologia', invece, è un sistema di notazione ideato da Joan e Rudolf Benesh nel $1956 \mathrm{e}$ adottato dal Royal Ballet di Londra. Si ispira alla cronofotografia di Etienne-Jules Marey per estrapolare l'essenza dei segni utili alla graficizzazione del corpo, ripreso posteriormente e inscritto in un pentagramma che ne suddivide le parti coniugando i tempi dell'azione performativa con la partitura musicale [Benesh, Benesh 1956].

Tra le forme di notazione, ampiamente riconosciute, si ricorda anche quella proposta da Noa Eshkol e Avraham Wachmann nel 1958 che, pur partendo da una capillare analisi e classificazione dei limiti posturali di un corpo disegnato, 'disseziona' il movimento dei singoli arti a partire dai loro centri, classificandone le rotazioni in piane e coniche all'interno di una matrice numerica che ne restituisce le coordinate in virtù dei moti spaziali [Eshkol, Wachmann 1958] (figg. 7-10).

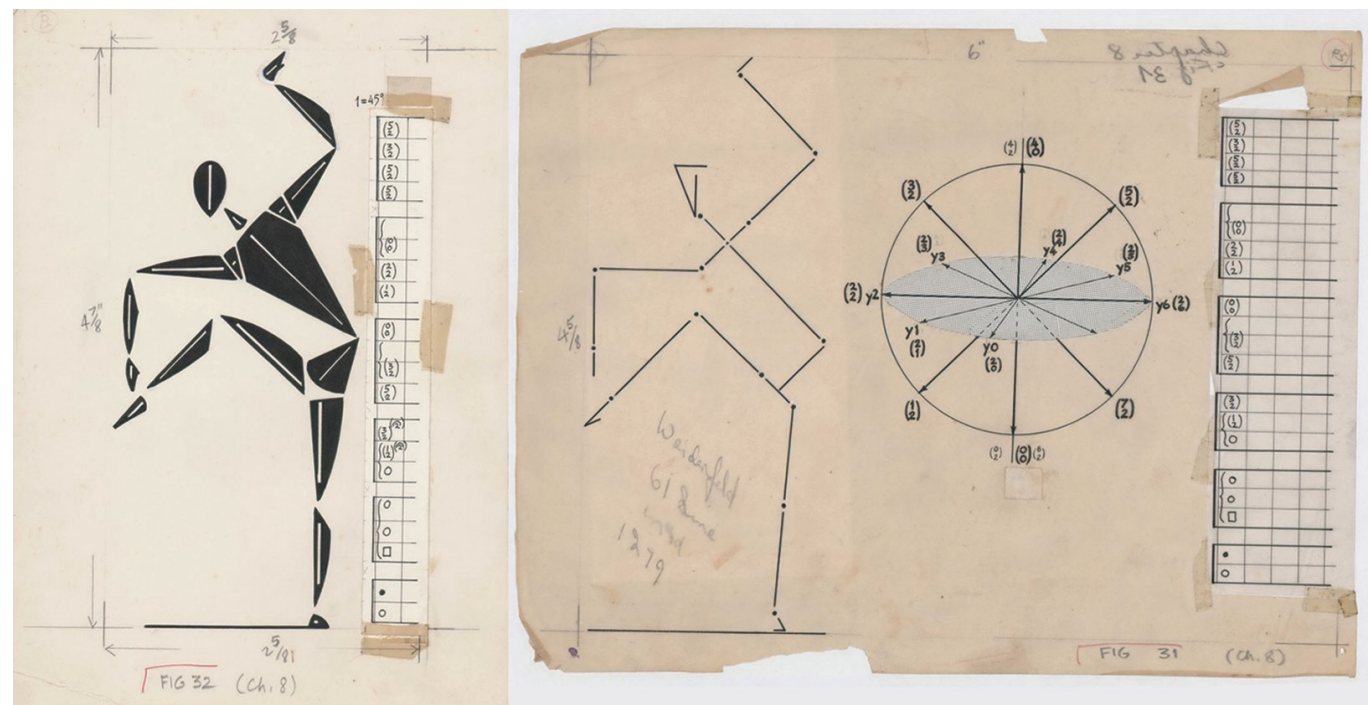


Seppur fondato su logiche matematiche analoghe a quelle utilizzate nel cinema di animazione 3D - che attraverso le tecniche del rigging vincola le catene cinematiche inverse allo scheletro di un avatar cui associare il movimento -, il sistema notazionale di Eshkol e Wachman non prevede alcuna convenzione grafica e sono proprio i ballerini a prendere le distanze da tutte quelle forme di astrazione comunicativa incapaci di instaurare un dialogo diretto con le azioni e le qualità dei gesti da compiere, anche quando si fa leva sull'arbitrio del simbolo grafico.

Se nel corso dei secoli i sistemi notazionali hanno espresso in numeri e simboli la natura olistica del movimento, già nel 1986 Antonio Camurri e altri studiosi evidenziavano la necessità di avvalersi di approcci computazionali, per restituire la complessità degli schemi motori che la rappresentazione digitale è in grado di attivare, perché unisce allo spazio tridimensionale la componente del tempo e del moto [Camurri, Morasso, Tagliasco, Zaccaria 1986].

Tra i pionieri delle tecnologie informatiche, intese come ausili di progettazione di una coreografia anti-narrativa, Merce Cunningham ha sperimentato aleatorie tecniche compositive, per concentrarsi sul dinamismo spaziale di un corpo liberato dai vincoli di separazione fra arte e vita. Come ricorda Laurence Louppe, la notazione di Cunningham disegna "semplicemente un modello di elementi che già esistono. Ad esempio, una tecnica

Fig. II. DanceForms 2.0, interfaccia grafica del software, Credo Interactive Inc. <http:// charactermotion.com> (consultato il 30 gennaio 2021)

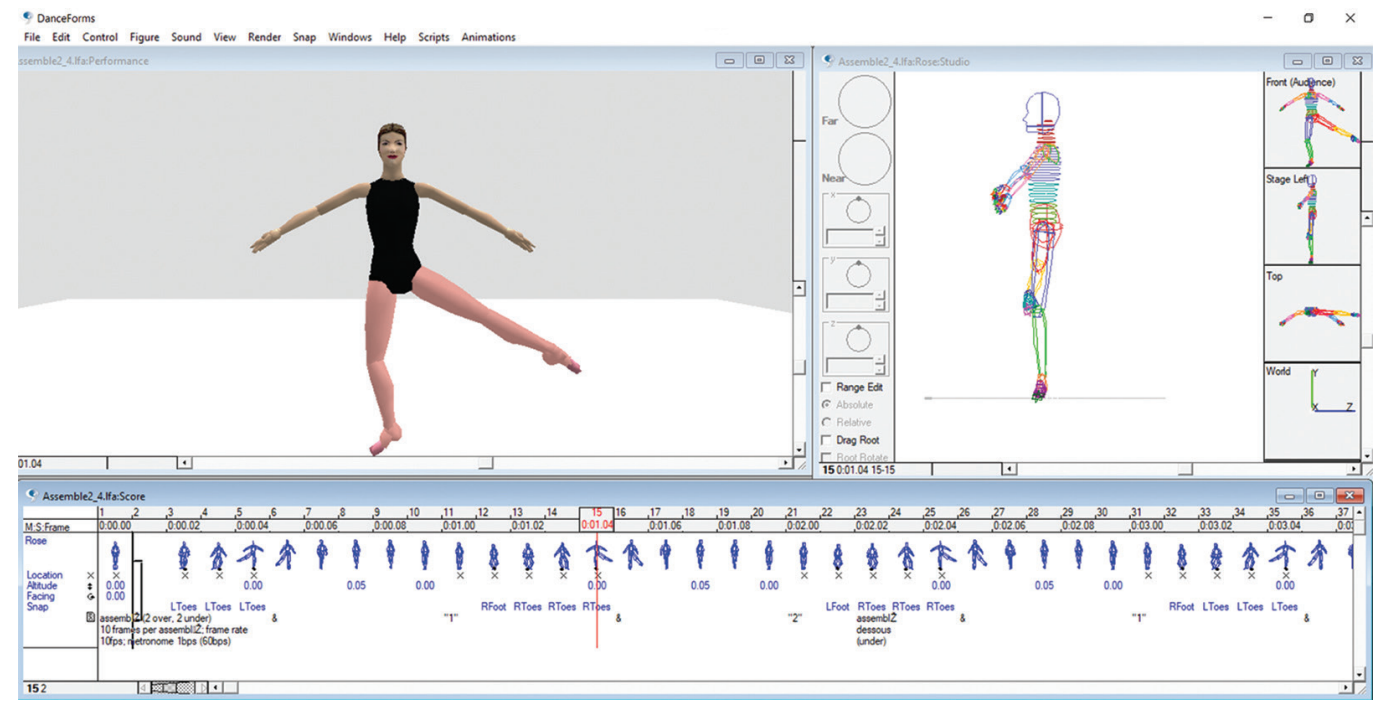

compositiva della danza consiste nel tenere un foglio sotto la luce, leggendo la potenziale coreografia costruita dalle imperfezioni visibili nelle trame della carta" [Louppe 20 I6, p. 63]. Ma l'azione impressa dalla presenza fisica, che le attraversa nello spazio performativo, struttura le sue figure a partire dall'uso di un software ideato dal coreografo già a partire dalla fine degli anni Sessanta.

DanceForms [2] è un'interfaccia di progettazione che permette di modellare molteplici posture di un avatar 3D, disposte lungo una timeline che ne interpola le trasformazioni animandole. II movimento si espleta assecondando le componenti principali del gesto, per come le sintetizzava Laban nei termini di spazio, sequenza e postura [Peressini 2020, pp. 175, I76] (fig. II).

Tuttavia, se l'alter ego digitale sembra dettare le regole di una coreografia da impartire ad una presenza reale, viceversa, il corpo del danzatore si sottopone alle programmate e ricorsive analisi qualitative, quando si dota di sensori a diretto contatto con la pelle che, grazie agli algoritmi di motion capture, restituiscono al software i loro esiti ascrivendoli ad 
un avatar 3D, per estrapolare da esso il potenziale espressivo del moto da compiere. I mezzi a disposizione, quindi, offrono alternative strade per documentare e divulgare la creazione della danza, rendendo le informazioni accessibili e finalmente comprensibili, tanto ai protagonisti della scena quanto al pubblico eterogeneo. Ad esempio, William Forsythe sperimenta i limiti dell'equilibrio corporeo nell'estrema velocità degli spostamenti che specchiano la sua grammatica coreografica, da apprendere grazie ad interfacce interattive che sovrappongono alle video riprese stratificazioni di informazioni multilivello, nella graficizzazione delle traiettorie geometriche della composizione spazio-temporale da interpretare.

Per attuare ciò, Improvisation Technology è un CD-ROM pubblicato e pensato per formare, anche a distanza, i ballerini della compagnia di Forsythe [Kuchelmeister, Haffner, Ziegler 2012]; Synchronus Object for One Flat Thing, invece, è una piattaforma web nata dalla collaborazione con Norah Zuniga Shaw e Maria Palazzi, dell'Advanced Computing Center for the Arts and Design dell'Ohio State University, il cui scopo è quello di registrare le sequenze progressive di ogni singolo ballerino, visualizzandole sotto forma di stratificate superfici curve che documentano le azioni dell'intera coreografia, così da poterla ripercorrere a ritroso per estrapolarne le singole componenti, indipendentemente dal soggetto che le performa [Forsythe, Zuniga Shaw, Palazzi 2009] (fig. I2).

L'astrazione del corpo, in un puro disegno animato che registra la memoria delle sue linee di attraversamento spaziale, ritorna in molti dei lavori dei coreografi odierni, tanto che il collettivo OpenEnded Group [3] lavora su un immaginario visivo fatto di proiezioni scenografiche congruenti con la resa stessa dello spettacolo, interrogandosi sulla possibilità che il movimento umano, proprio in assenza di un corpo, possa nel disegno di tracce rettilinee e curve restituire il ritmo e la sostanza della coreografia [Molesworth 20 | I, p. | | 4]. È proprio nella stretta relazione che intercorre fra presenza incarnata del ballerino e visualizzazione in tempo reale del moto, impartito dal suo evanescente clone digitale, che la rappresentazione esibisce il valore semantico di un linguaggio universalizzante, adatto alla formazione, alla documentazione e divulgazione della danza. Ma per quanto la scena contemporanea, apparentemente, sembri aver sostituito il concetto di 'notazione' con quello di annotazione [deLahunta, Jenett 20 l6], intesa come pratica progettuale che stratifica gli esiti di più medium spaziando dalla video ripresa, alla modellazione e animazione 3D, alle tecniche di motion capture orientate alla codifica qualitativa del movimento, si dimostra che il coreografo odierno continua ad ambire alla creazione di un proprio sistema notazionale, scegliendo come linguaggio di comunicazione preferenziale il disegno.

Fig. 12. William Forsythe, Norah Zuniga Shaw, Maria Palazzi, Synchronus Object for One Flat Thing. reproduced by William Forsythe. Form flow, Cue visualizer tool, Difference forms, 3 D alignment forms. Per a forms. Per gentile conUnione dit Ohio state niversity e Forsythe Company.

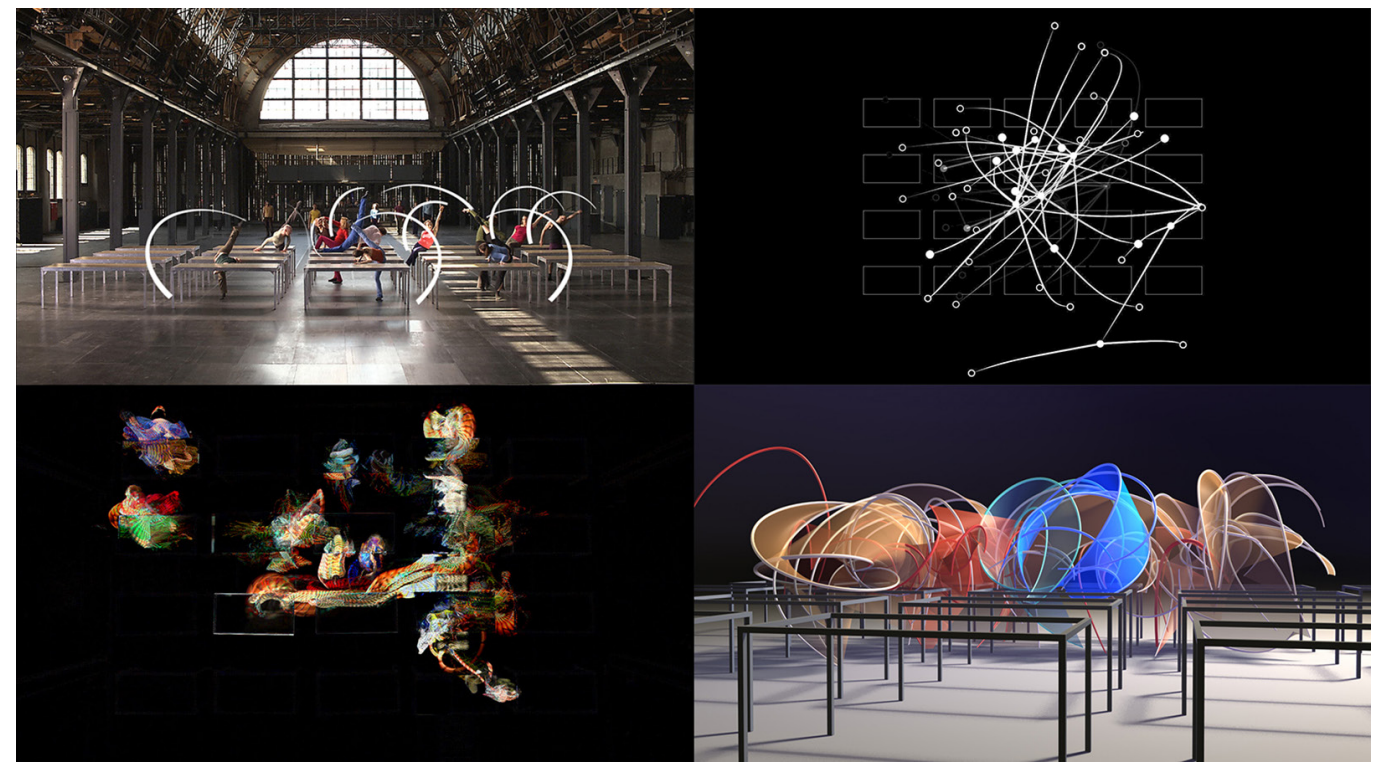




\section{Note}

[I] Kinetography o Labanotation

[2] Giunto alla versione 2.0, il software è prodotto da Credo Interactive Inc. <http://charactermotion.com> (consultato il 30 gennaio 2021) ed è l'evoluzione di Life Forms, concepito nel I991.

[3] OpenEnded Group è fondato da Marc Downey, Shelley Eshkar e Paul Kaiser: <http://openendedgroup.com> (consultato il 30 gennaio 2021 )

\section{Riferimenti bibliografici}

Benesh R., Benesh J. (1956). An Introduction to Benesh Dance Notation. London: A. \& C. Black.

Camurri A., Morasso P.. Tagliasco V., Zaccaria R. (1986). Dance and Movement Notation. In P. Morasso, V. Tagliasco. Human Movement Understanding. From Computational Geometry to Artificial Intelligence. Amsterdam: North-Holland, pp. 84- 124.

deLahunta S. Jenett F. (2016). Making digital choreographic object interrelate: A focus on coding practices. In M. Leeker, I. Schipper, T. Beyes. Performing the Digital. Performance Studies and Performances in Digital Cultures. Bielefeld:Verlag, pp. 63-79.

Eshkol N., Wachmann A. (1958). Movement Notation. London:Weidenfeld and Nicolson.

Feuillet M. (1700). Choregraphie ou L'Art de Décrire la dance, par caracteres, figures et signes démonstratifs, Avec lesquels on apprend facilement de soi-même toutes sortes des Dances. Paris: Chez l'Auteur.

Forsythe W., Zuniga Shaw N., Palazzi M. (2009). Synchronous Objects for One Flat Thing, reproduced by William Forsythe. <https:// synchronousobjects.osu.edu> (consultato il 10 febbraio 2021).

Hutchinson Guest A. (1984). Dance Notation. The process of recording movement on paper. New York: Dance Horizons

Hutchinson Guest A. (1998). Choreo-Graphics. A Comparison of Dance Notation Systems From the Fifteenth Century to the Present. London-New York: Routledge.

Kuchelmeister V., Haffner N., Ziegler C. (20I2). William Forsythe. Improvisation Technologies. A Tool for the Analytical Dance Eye. Berlin: Hatje Cantz.

L'Abbé A. (I 725 ca.). A New Collection of Dances, Containing a great Number of the best Ball and Stage Dances: Composed by Monsieur L'Abbe, Dancing-Master to Their Royal Highnesses, the Three Young Princesses. London: Roussau.

Laban R. (1928). Schrift Tanz. Wien: Universal Edition.

Louppe L. (20 I 6). Traces of Dance. Drawing and Notations of Choreophers. Paris: Dis Voir.

Molesworth H. (20 I I). Dance / Draw. Boston: Hatje Cantz.

Peressini G. (2020). Design e tecnologie digitali per la danza. Dispositivi di progettazione coreografica del movimento. Tesi di dottorato di ricerca in Scienze del design, Scuola di dottorato in Architettura, città e design. Tutor prof. M. Ciammaichella. Università luav di Venezia.

Pierce K. (1998). Dance Notation Systems in Late 17th-Century France. In Early Music, vol. 26, n. 2, 1998, pp. 286-299.

Pontremoli A. (2006). La danza. Storia, teoria, estetica nel Novecento. Roma-Bari: Laterza.

Saint-Léon A. ( 1852). La Sténochoréographie, ou Art d'écrire promptement la Danse avec portraits et biographies des plus célèbres Maitres de Ballets ancient et modernes; par Arthur Saint-Léon, ler maitre de ballets, \& I er Danseur de L'Opéra. Paris: Imprimerie de Moquet.

Tomlinson K. (1735). The Art of Dancing. Explained by Reading and Figures; Whereby the Manner of Performing the Steps is Made Easy By a New and Familiar Method: Being the Original Work. First design'd in the Year 1 724, and now Published by Kellom Tomlinson, Dancing-Master. In Two Books. London: Printed for the Author.

Tufte E. R. (1990). Envisioning information. Cheshire: Graphics Press.

Zorn F. A. ( I 887) Grammatik der Tanzkunst theoretischer und praktischer Unterricht in der Tanzkunst und Tanzschreibkunst oder Choregraphie. Leipzig: |.J.Weber

Autore

Massimiliano Ciammaichella, Università luav di Venezia, massimiliano.ciammaichella@iuav.it

Per citare questo capitolo: Ciammaichella Massimiliano (2021). Il disegno della danza. Notazione e controllo dello spazio performativo/Drawing of the Dance. Notation and performative space control. In Arena A., Arena M., Mediati D., Raffa P. (a cura di). Connettere. Un disegno per annodare e tessere. Linguaggi Distanze Tecnologie. Atti del $42^{\circ}$ Convegno Internazionale dei Docenti delle Discipline della Rappresentazione/Connecting. Drawing for weaving relationship. Languages Distances Technologies. Proceedings of the 42th International Conference of Representation Disciplines Teachers. Milano: FrancoAngeli, pp. | $47|-| 488$ 


\title{
Drawing of the Dance. Notation and Performative Space Control
}

\author{
Massimiliano Ciammaichella
}

\section{Abstract}

For the dance discipline, drawing always has had a central role in the choreography design, even if history shows how in the twentieth century representation, oriented to the semantising of a immediately understandable practice, seems to be replaced by graphic codes and numerical combinations that abstract its meaning.

The primary investigation objects are precisely the notational systems of dance, widespread since the end of the seventeenth century by various choreographers, authors of illustrated treatises which document, in the two-dimensional synthesis of the paper support, the complexity of space-time trajectories, postures and movements of the limbs involved in the choreographic action to be interpreted. Often, dancers are who distance themselves from these transcription forms because they are unable to read and translate them.

Therefore, the paper investigates the theories and methods of notation graphical transposition to understand their design principles, highlighting how all the analysed case studies originate from the study of the body and its kinematics. But digital technologies encourage new representation paradigms, demonstrating how contemporary experiences break down those very distances mentioned above, becoming the test bench for experiments in which the embodied body and its digital clone entertain an open dialogue with the notational systems of dance.

\section{Keywords}

human body, notation, choreography, 3D animation, motion capture.

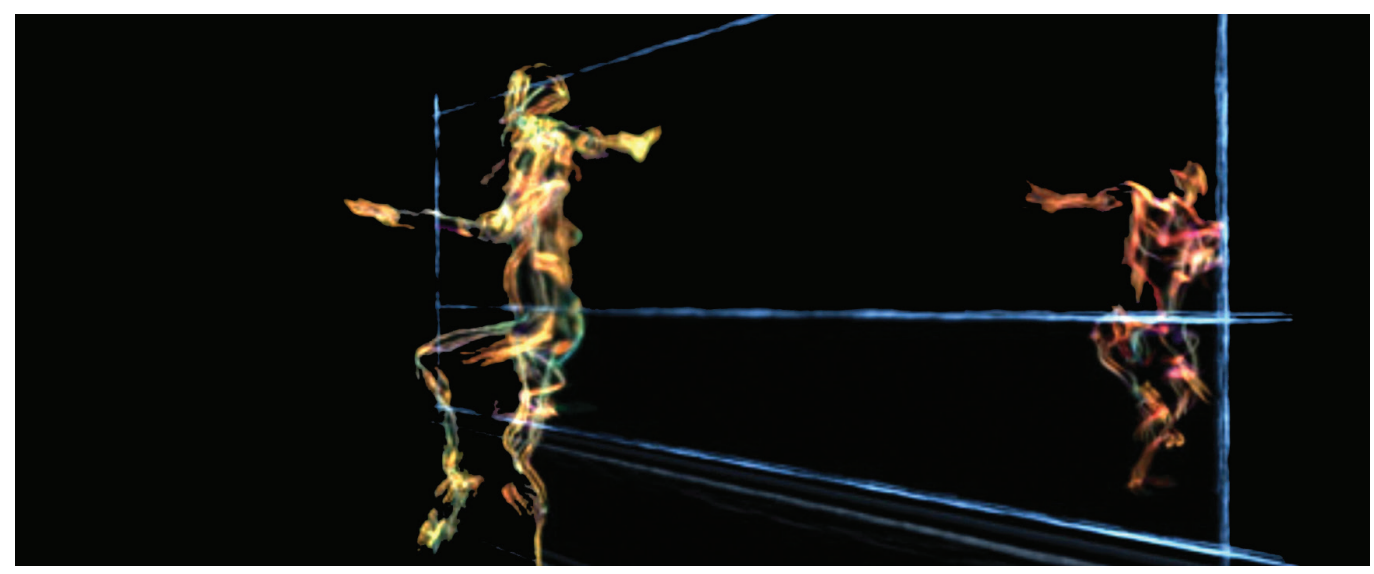


The dance languages, understood as a discipline that distances itself from the free body expression, in order to subject it to the austere rules of designed choreography, have trusted over the centuries on the search for unifying forms of signs transcription, made up of graphic codes suitable of translating the perfectible movement in the performance enclosed by perimeter of the stage action space.

Historically, the choice to regulate the physical gestures, posture and trajectories of a reproducible motion activated by music originated in the France of the Sun King, who in I66 I founded the Académie Royale de Danse and had it directed by the court dance master Pierre Beauchamp, between 1680 and 1687.

In this context, the choreographer experimented with and perfected the five basic positions of classical dance, also taking up Louis XIV's invitation to develop a notation system able of dialoguing with the transcription of the musical score. Thus, his learner Raoul Auger Feuillet published a treatise on choreography in 1700, manifesting in the title, for the first time, the desire to express ballet in terms of character and demonstrative figure [Feuillet 1700].

In compliance with the declaration, the development of a language based on a visual lexicon is expressed in the construction of an alphabet of postures confronting with the two-dimensional space, traced by the curved geometries of actions calibrated by a physicality that measures and redesigns it through its movement.

It starts from the body position, schematised by a rectilinear sign connected by a circumference arc that indicates its orientation, then continues with the graphic representation of the feet five positions, stylised by straight lines and circles that identify the support of the heel, to arrive at the trajectories definition, straight or curved, which are interrupted by one or more segments that determine the specifications of the step to be taken: bent; elevated; simply jumped or cabriole, on one foot touched in the air by the other before reaching the ground in unison; falling down and glided (fig. I).

This notation system was also widely used in other countries and perhaps offers us the only way to trace the original historical choreographies interpretation, in line with Beauchamp's idea of constructing a recording court's and opera's ballets method, in such a way that they could be learnt independently, without the help of a master [Pierce 1998, p. 290].
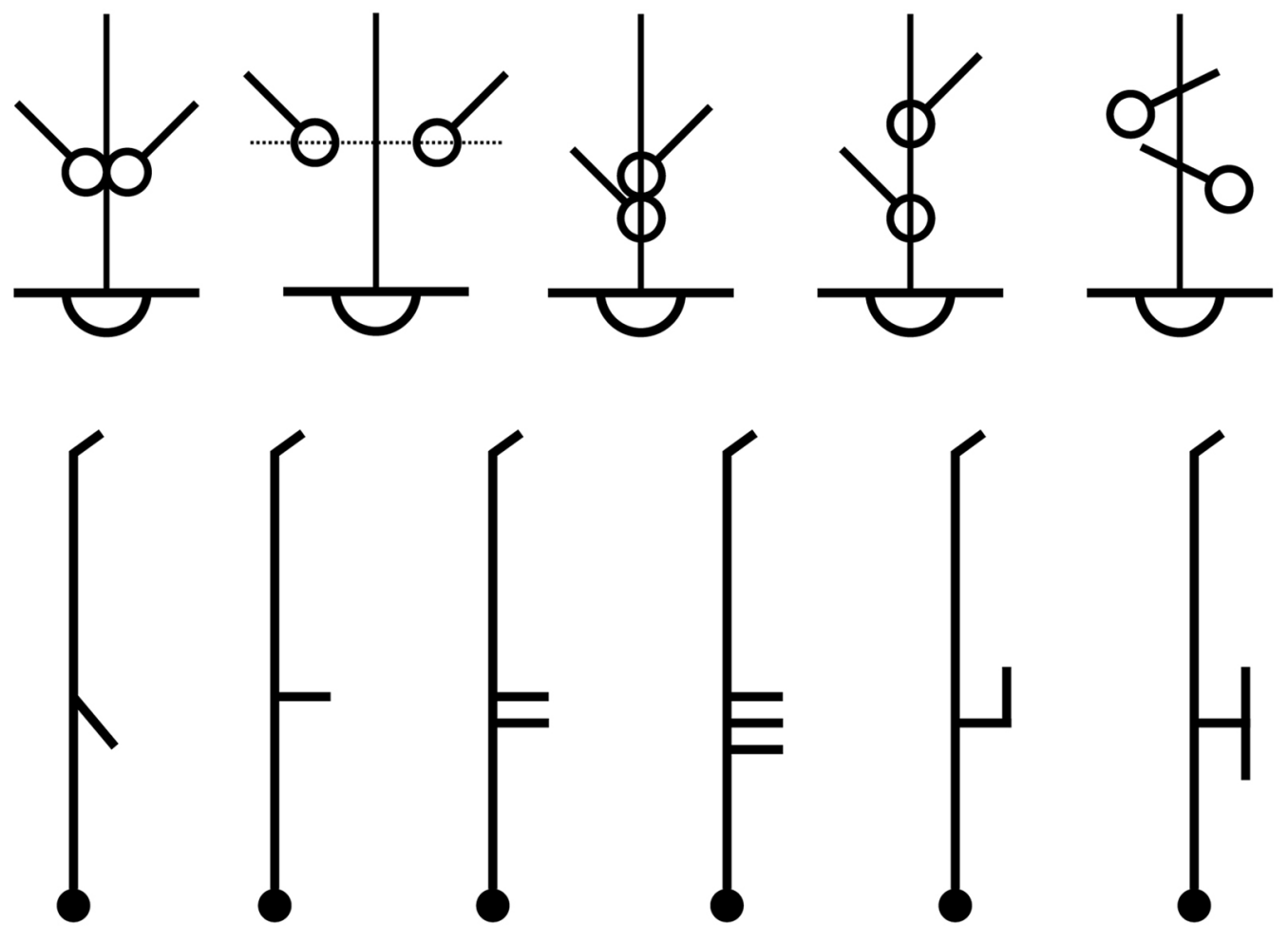
But the illustrations limitations lie in the plane distribution of a complex symbols set that privileges ichnographic projection, without confronting the dancers' movements real scale as they modulate the sequences. Thus, the desire to make the representation subjective -in the publications of twenties and thirties years of eighteenth century- is confronted with the central perspectives of neutral spaces inhabited by bodies, which render objective the emphasis on symmetry imposed by couples' dances, as can be seen, for example, in the engravings collected in the volumes of Anthony L'Abbé and Kellom Tomlinson [L'Abbé I 725 ca.; Tomlinson 1735].

These images historicize movements and costumes attributable to the period in which they were produced. They place the accent on the posture of legs and support of the feet, in the graphic communication of a choreographic expression that is decidedly functional to the late Baroque aesthetic, entirely focused on the step to be taken importance and less on the arms articulations, often open forward to highlight the hands poses that never exceed shoulder height (figs. 2, 3).

Fig. 2. Anthony L'Abbé, Chacone [L'Abbé A. I725 ca., p. 22].

Fig. 3. Kellom Tomlinson, Passacaille Tomlinson K I735, p. 200].
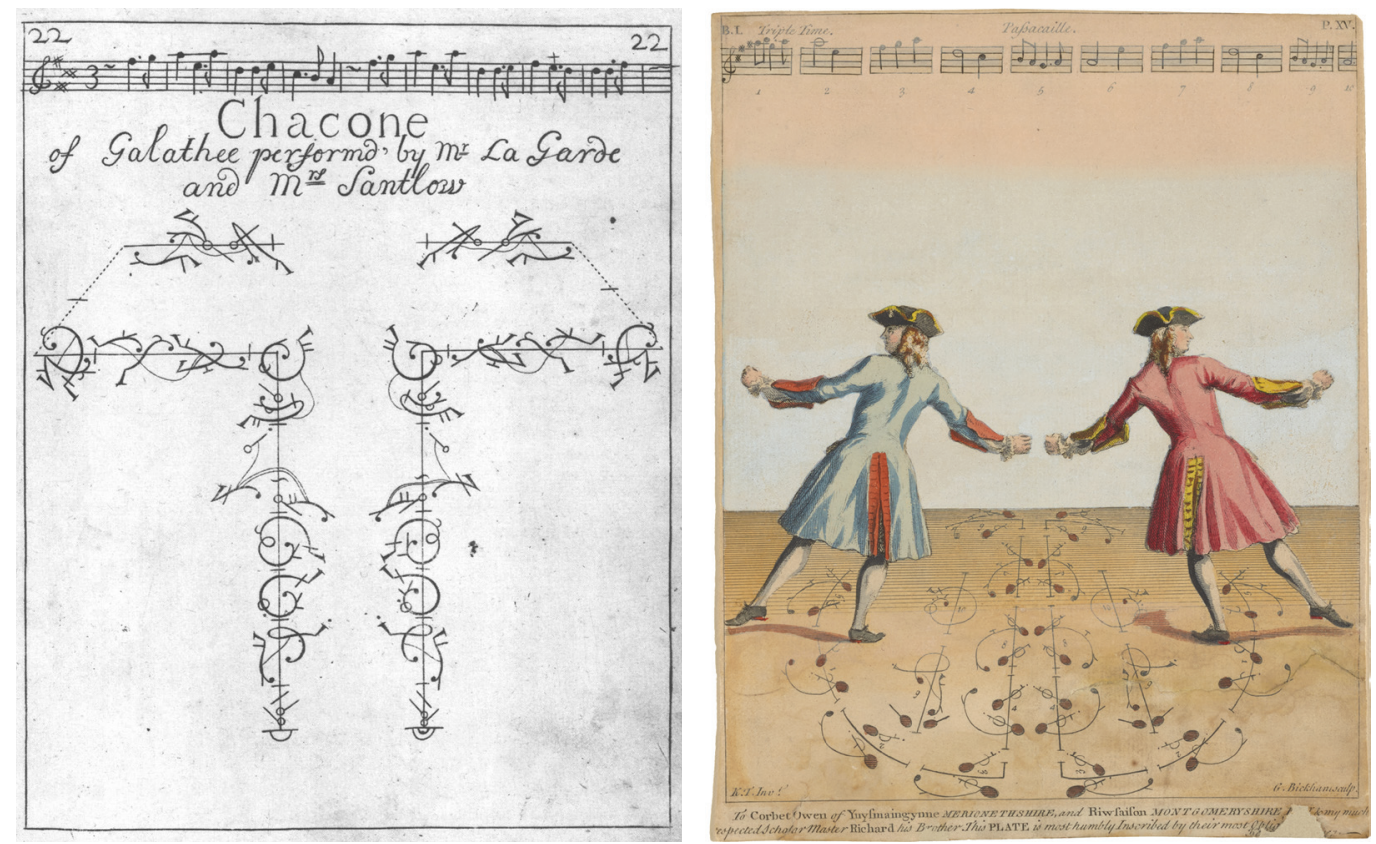

In the evolution of styles, the choreographers willingness to find a specific and effective communication of the correct danced movement, in useful images to make it reproducible, becomes a necessity. This is demonstrated trough the continuous proposals of notational systems that multiplied in the nineteenth century, rationalising a complex of information such as time, space, and physical action, on a two-dimensional support which then focused on orthographic representation.

The drawing of the body is shown, albeit in the essential traits of its recognisability, but this is probably due to the evolution of increasingly light and close-fitting stage costumes that enhance the features [Hutchinson Guest 1984, p. 68]. Thus, in Arthur Saint-Léon's sténochoréographie of 1852, a range of signs - which classified the actions of the torso upper part, separating them from the lower part- offers a wide range of combinations, the interpretation of which, paradoxically, is addressed to the public that observes the scene from the front and not to the dancer who has to reverse the reading, arranged on a choreographic pentagram ordered by the technique and the trajectories description of spatial movement [Saint-Léon 1852]. 
The method proposed by Saint-Léon is simplified by Frederich Albert Zorn, in Grammatik derTanzkunst del I 887 [Zorn I887].

The representations of the atlas accompany the volume explaining the logic of an anthropomorphic synthesis drawn, deduced from the motion limits geometry imposed by the limbs, in the sequences shown frontally and in profile, so as to cadence the musical timing of the single choreographic configurations, all anticipated by a synthetic perspective schematisation of the entire kinetic design, traced on the surface of the stage (figs. 4, 5).
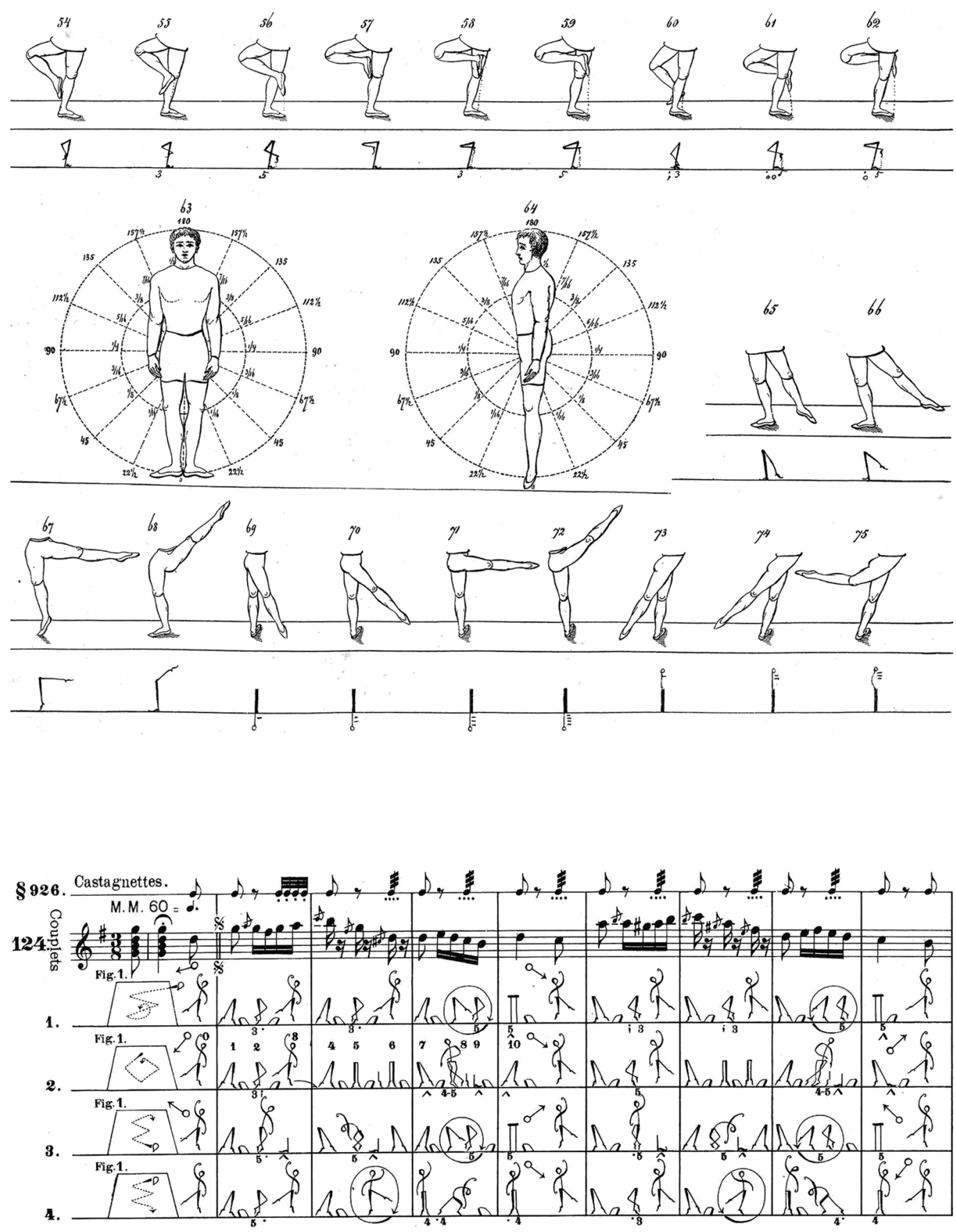
Although nineteenth-century experimentations arrive at an intelligible form of the drawn body, which activates its performing motions recorded by sequences of postural frames, twentieth-century proposals, on the contrary, seem to cancel its presence.

The human body is deprived of its immanent recognisability, as it is replaced by the apparent constructive functionality of complex visual glossaries that purport to describe the wide range of possible motor actions.

According to Edward Tufte, in general, this spasmodic urgency to construct a graphic language that universalising choreographic expression -regardless of the methods chosen for its representative description - rather than operating a symbiosis between scientificity and narration, has put in crisis their inevitable relationship [Tufte 1990, pp. I18, I19].

Actually, being able to synthesise in the two-dimensionality of a synoptic table, the complex of information needed to understand the set of movements to be performed, according to the time and space of action means dealing with models of representation oriented towards the abstraction of plane geometries, which can be translated into graphic codes that must be learnt before being read and interpreted.

Some of the most accredited notational systems, still used today, such as the kinetography [I] theorised by Rudolf Laban in 1928, are born from the direct observation of the postural combinations offered by the dancer body, who implements them within an icosahedral structure, in order to extrapolate from empirical practice the theoretical model within which to trace motion geographies. Laban defines it in terms of a kinesphere whose surface is touched by the limbs at points that determine the visual codes necessary for composition [Laban 1928]. Rectangles, trapeziums and triangles - with three different textures that symbolise the height of the limbs involved- are positioned in a rigorous visual apparatus that can be read from bottom to top, tripartite by vertical bands that frame the actions of the lateral and central extremities of the body (fig. 6).

Fig. 6. Massimiliano Ciammaichella, reconstruction of the kinesphere and graphic symbols for the dance notation system proposed by Rudolf Laban in 1928.
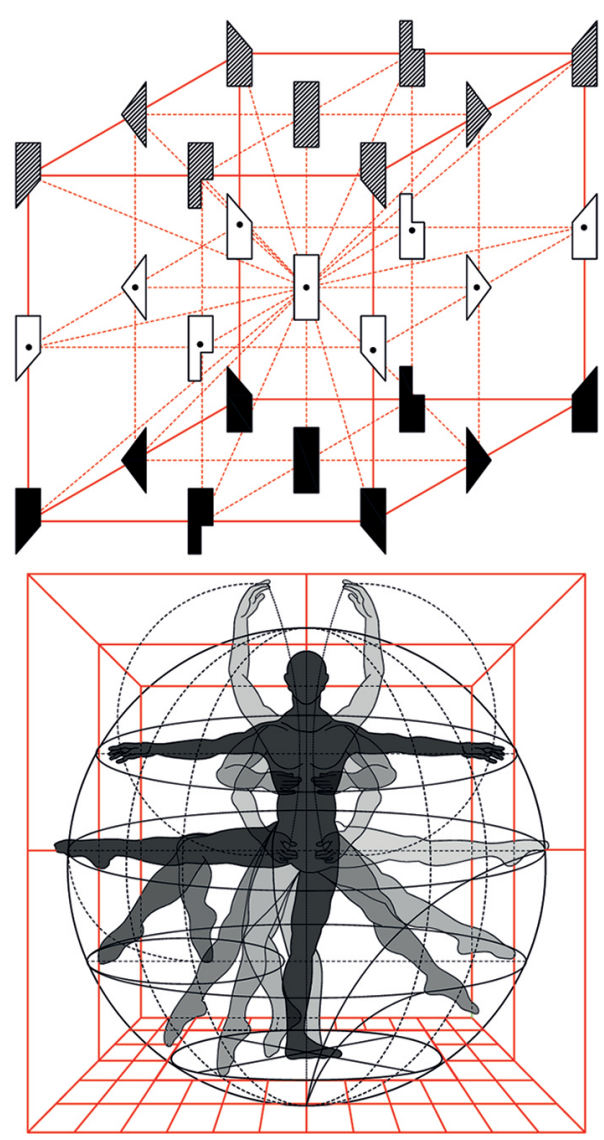
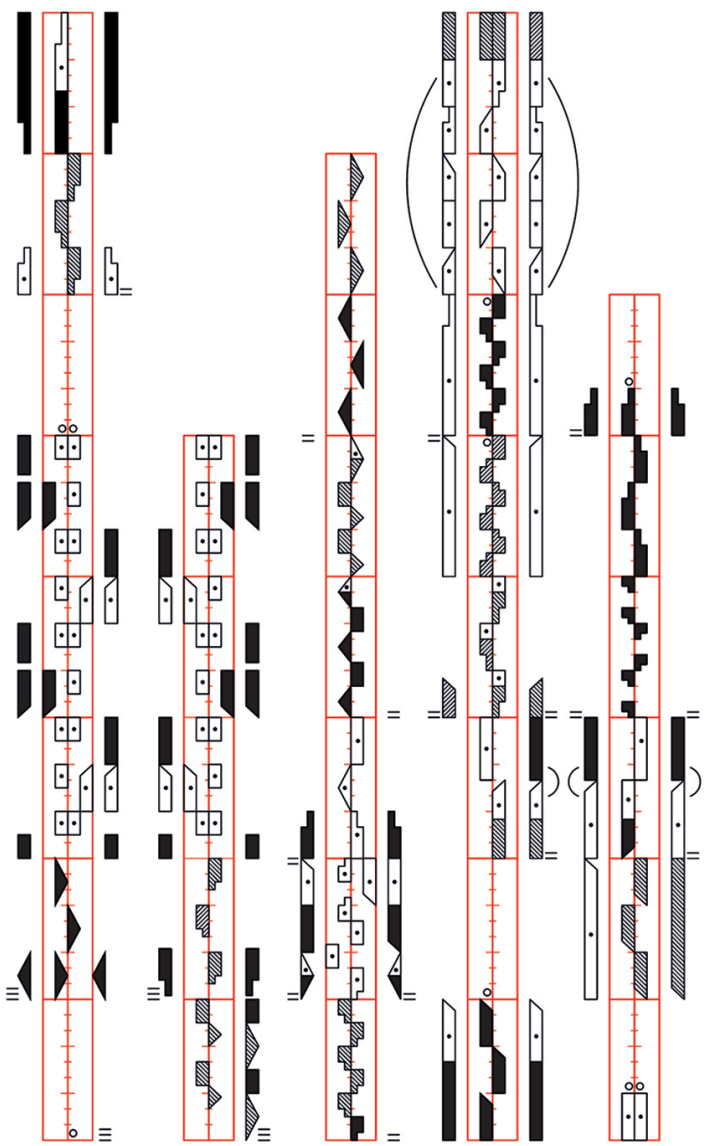
Fig. 7. Avraham Wachman The main and Private system of reference, 1950 s. Ink and collage on papera $20 \times 20 \mathrm{~cm}$. (Courtesy Noa Eshkol Foundatio for Movement Notation)

Fig. 8. John G. Harries, Conical movement, 1950s. Ink and collage on paper. $30.5 \times 25 \mathrm{~cm}$. (Courtesy Noa Eshkol Foundation for Movement Notation)

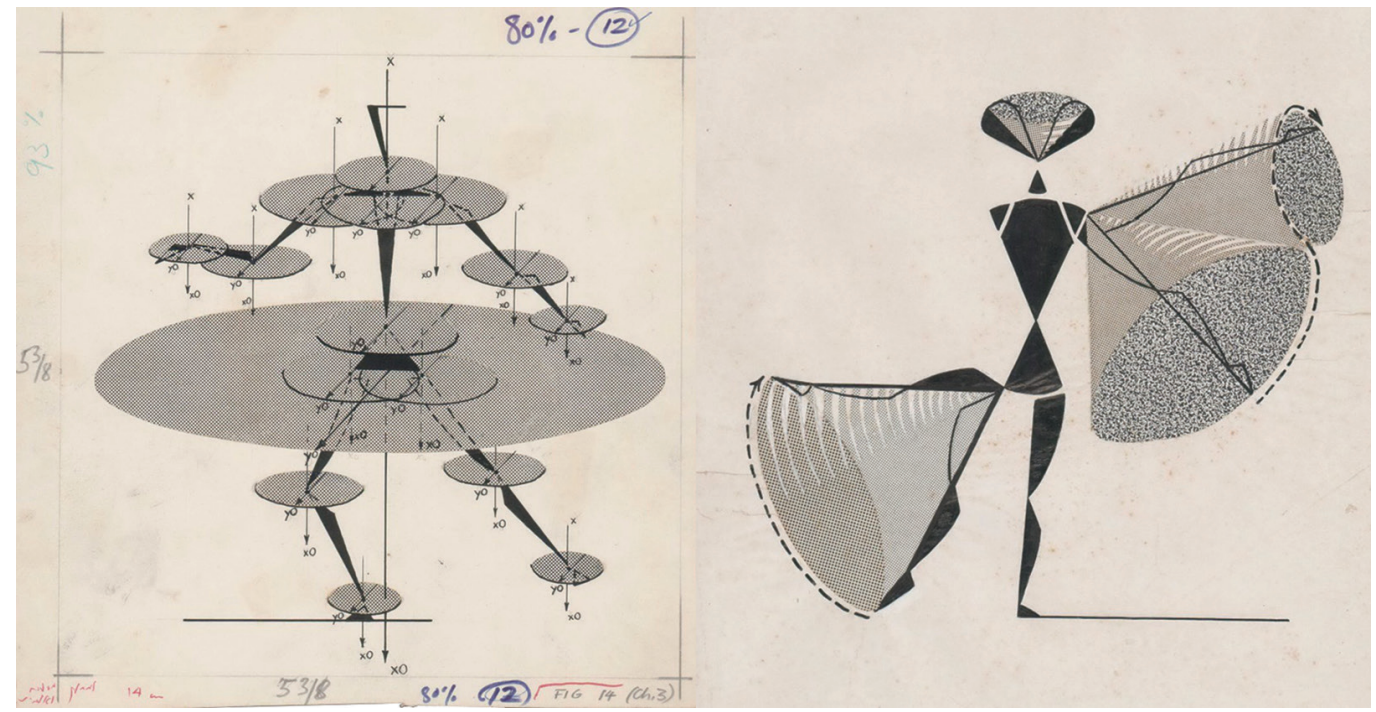

Laban's method presents analogies with the one proposed by Feuillet, however it does not allow the immediate directions recognition of the spatial path to be taken, for which it is necessary use to further graphic symbols [Pontremoli 2004, pp. 60, 6I].

Choreology, on the other hand, is a notation system created by Joan and Rudolf Benesh in 1956 and used by the Royal Ballet of London. It is inspired by the chronophotography of Etienne-Jules Marey to extrapolate the useful essence signs for the body description, framed from behind and inscribed in a pentagram that subdivides its parts, combining the times of the performance with the musical score [Benesh, Benesh 1956].

One of the widely recognised forms of notation is that proposed by Noa Eshkol and Avraham Wachmann in 1958, which, while starting from a detailed analysis and classification of the postural limits of a drawn body, dissects the movement of the individual limbs starting from their centres, classifying their rotations into planes and cones within a numerical matrix that show the coordinates of the spatial motions [Eshkol, Wachmann 1958] (figs. 7- I0). Although based on mathematical logic similar to that used in 3D animation cinema - which,

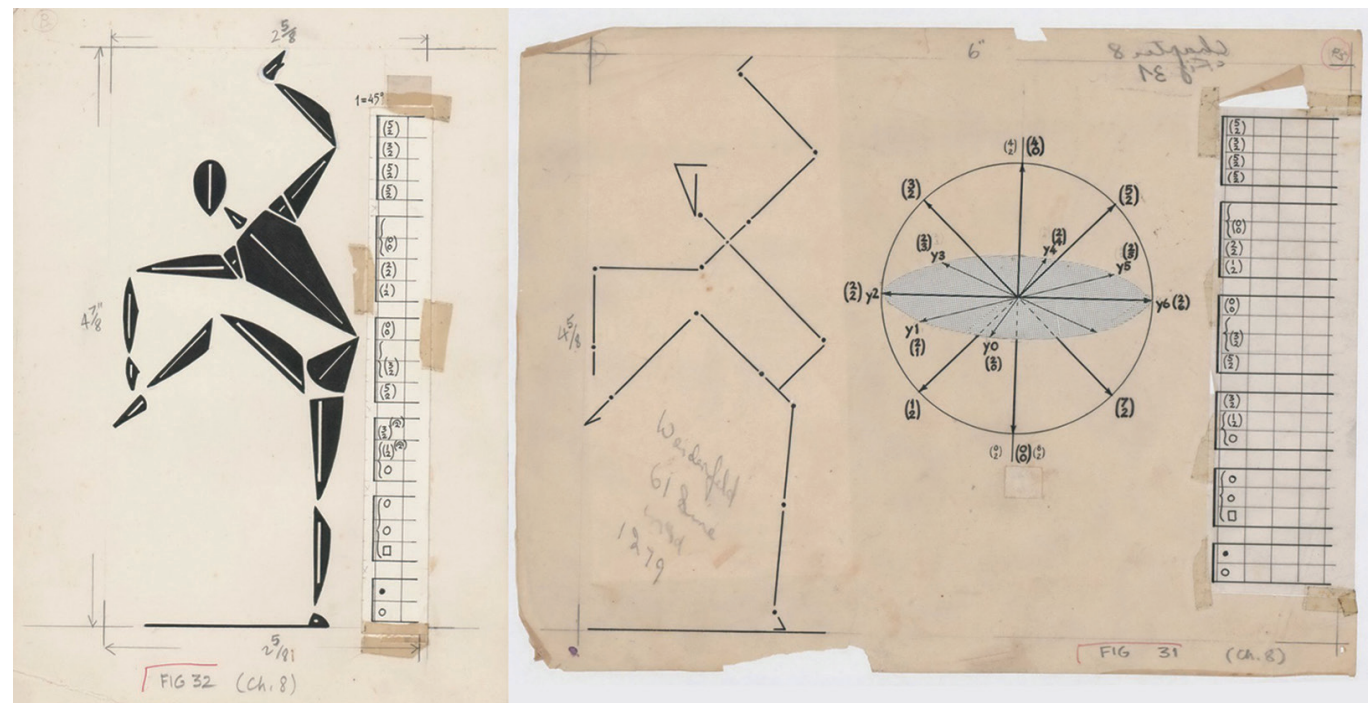

Fig. 9. John G. Harries, Analysis of a position of on the manuscipt page. 1950s. Ink $\times 19 \mathrm{~cm}$ (Courtesy 27 Eshkol Foundary Movement Notation).

Fig. 10. Avraham Wachman, Analysis of a position of the whole stick figure, System of reference, and manuscript page, 1950s. Ink and collage on parchment $24 \times 31.5 \mathrm{~cm}$. (Courtesy Noa Eshkol Foundation for Movement Notation). 
through rigging techniques, connects the inverse kinematic chains to the skeleton of an avatar which movement is associated- Eshkol and Wachman's notation system does not provide for any graphic conventions, and the dancers are who distance themselves from all those forms of communicative abstraction incapable of determining a direct dialogue with the actions and qualities of gestures to be made, even when these relying on the arbitrariness of the graphic symbol.

While over the centuries notational systems have expressed the holistic nature of movement in numbers and symbols, as early as 1986 Antonio Camurri and other scholars highlighted the need to make use of computational approaches, in order to restore the complexity of motor schemes that digital representation is able to activate, because it combines three-dimensional space with the time and motion components [Camurri, Morasso, Tagliasco, Zaccaria 1986].

One of the pioneers of computer technology as a design aid for non-narrative choreography, Merce Cunningham, experimented with aleatory compositional techniques to focus on the spatial dynamism of a body freed from the separation constraints between art and life. As Laurence Louppe writes, Cunningham's notation draws "out the pattern of elements which already exist. For example, one technique in dance composition involves holding up a sheet of paper to the light and reading a potential choreography from the imperfections

Fig. I I. DanceForms 2.0, software graphic interface, Credo Interactive Inc. <http://charactermotion com> (accessed 2021, January 30 ).

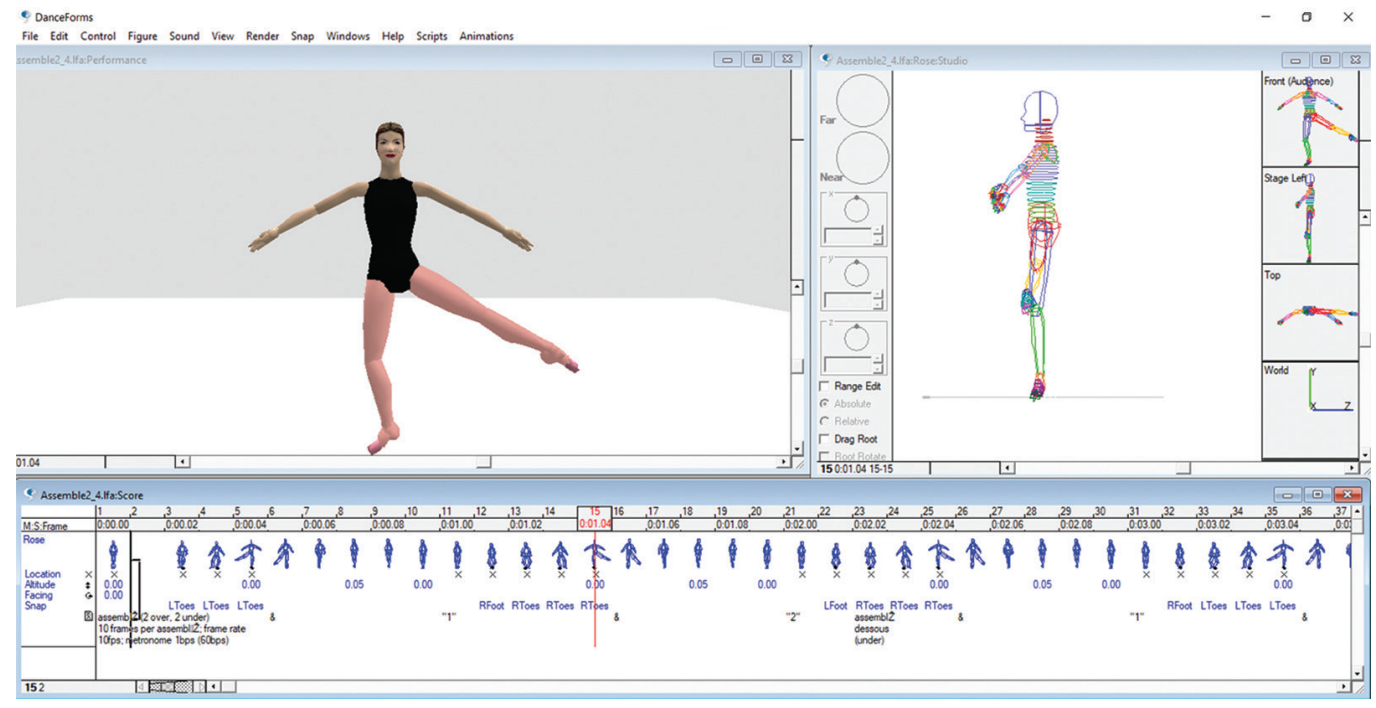

visible in the texture of the page" [Louppe 2016, p. 63]. But the action imprinted by the physical presence, which traverses them in the performance space, structures its figures from the use of software theorized by the choreographer as early as the late sixties.

DanceForms [2] is a design interface that allows many postures of a 3D avatar to be modelled, arranged along a timeline that interpolates the transformations by animating them. The movement is constructed by following the main components of the gesture, for how are summarised by Laban in terms of space, sequence, and body posture [Peressini 2020, pp. 175, I76] (fig. II).

However, if the digital alter ego seems to set the rules of choreography to be imparted to a real presence, vice versa, the dancer submits its body the programmed and recursive qualitative analyses, when it is equipped with sensors in direct contact with the skin which, thanks to motion capture algorithms, return their results to the software, ascribing them to a 3D avatar, extrapolate from it the expressive potential of the movement to be performed. The means available therefore offer alternative ways of documenting and disseminating 
dance creation, making information accessible and finally comprehensible, both to the protagonists of the scene and to the heterogeneous public. For example, William Forsythe experiments with the limits of bodily balance in the extreme speed of the movements that mirror his choreographic grammar, to be learnt thanks to interactive interfaces that stratify layers of multi-level information on the video footage, in the drawing of trajectories of the space-time composition to be interpreted.

To implement this, Improvisation Technology is a CD-ROM published and designed to train, even at a distance, the dancers of Forsythe's company [Kuchelmeister, Haffner, Ziegler 20 I2]; Synchronus Object for One FlatThing, on the other hand, is a web platform created in collaboration with Norah Zuniga Shaw and Maria Palazzi, of the Advanced Computing Center for the Arts and Design at Ohio State University, whose aim is to record the progressive sequences of each dancer, visualising them in the form of stratified curved surfaces that document the actions of the entire choreography, so that it can be retraced backwards to extrapolate the individual components, independently of the person performing them [Forsythe, Zuniga Shaw, Palazzi 2009] (figs. 12).

The body abstraction, in a pure animated drawing that records the memory of its lines of spatial crossing, returns in many of the works of today's choreographers, so much so that the OpenEnded Group collective [3] works on visual imagery made up of scenic projections congruent with the performance itself, questioning the possibility that human motion, precisely in the absence of a body, can in the drawing of rectilinear and curved traces give back the rhythm and substance of the choreography [Molesworth 20 I I, p. I I 4].

It is precisely in the close relationship established between the embodied presence of the dancer and the real-time visualisation of the movement, imparted by his evanescent digital clone, that the representation displays the semantic value of a universalising language, suitable for training, documentation and dissemination of dance. But however much the contemporary scene seems to have replaced the concept of 'notation' with that of 'annotation' [deLahunta, Jenett 20 I6], understood as a design practice that stratifies the results of several mediums, ranging from video filming, to 3D modelling and animation, to motion capture techniques oriented towards the qualitative codification of movement, it demonstrates that today's choreographer continues to aim for the creation of his notational system, choosing drawing as his preferred language of communication.

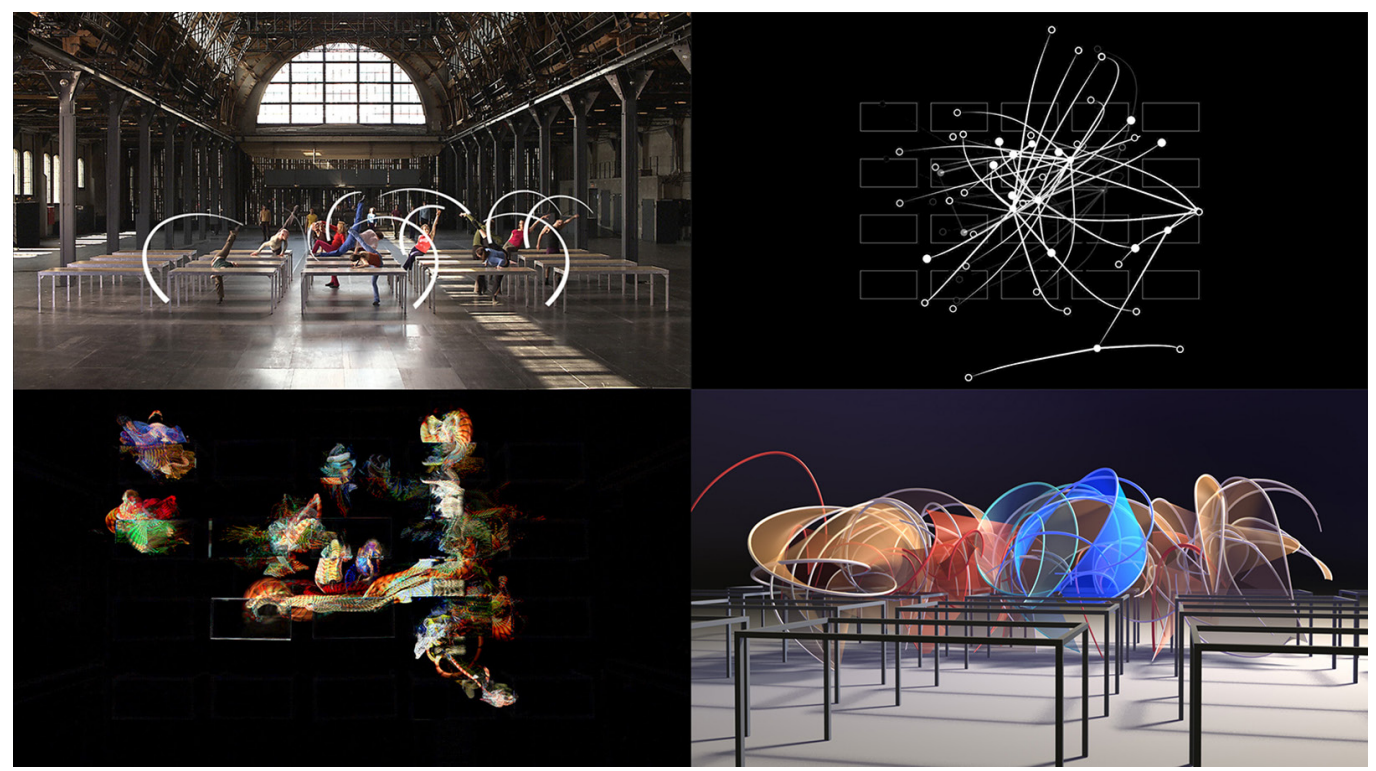




\section{Notes}

[I] Kinetography or Labanotation.

[2] Now in 2.0 version, the software is produced by Credo Interactive Inc. http://charactermotion.com (accessed 202 I, January 30) and is an evolution of Life Forms, produced in 1991.

[3] OpenEnded Group is founded by Marc Downey, Shelley Eshkar and Paul Kaiser <http://openendedgroup.com> (accessed 2021, January 30).

\section{References}

Benesh R., Benesh J. (1956). An Introduction to Benesh Dance Notation. London: A. \& C. Black.

Camurri A., Morasso P., Tagliasco V., Zaccaria R. (1986). Dance and Movement Notation. In P. Morasso, V. Tagliasco. Human Movement Understanding. From Computational Geometry to Artificial Intelligence. Amsterdam: North-Holland, pp. 84- I 24.

deLahunta S. Jenett F. (2016). Making digital choreographic object interrelate: A focus on coding practices. In M. Leeker, I. Schipper, T. Beyes. Performing the Digital. Performance Studies and Performances in Digital Cultures. Bielefeld:Verlag, pp. 63-79.

Eshkol N., Wachmann A. (1958). Movement Notation. London:Weidenfeld and Nicolson.

Feuillet M. (I700). Choregraphie ou L'Art de Décrire la dance, par caracteres, figures et signes démonstratifs, Avec lesquels on apprend facilement de soi-même toutes sortes des Dances. Paris: Chez l'Auteur.

Forsythe W., Zuniga Shaw N., Palazzi M. (2009). Synchronous Objects for One Flat Thing, reproduced by William Forsythe. <https:// synchronousobjects.osu.edu> (accessed 2021, February 10).

Hutchinson Guest A. ( 1984). Dance Notation. The process of recording movement on paper. New York: Dance Horizons.

Hutchinson Guest A. (1998). Choreo-Graphics. A Comparison of Dance Notation Systems From the Fifteenth Century to the Present. London-New York: Routledge.

Kuchelmeister V., Haffner N., Ziegler C. (2012). William Forsythe. Improvisation Technologies. A Tool for the Analytical Dance Eye. Berlin: Hatje Cantz.

L'Abbé A. (I 725 ca.). A New Collection of Dances, Containing a great Number of the best Ball and Stage Dances: Composed by Monsieur L'Abbe, Dancing-Master to Their Royal Highnesses, the Three Young Princesses. London: Roussau.

Laban R. (1928). Schrift Tanz. Wien: Universal Edition.

Louppe L. (2016). Traces of Dance. Drawing and Notations of Choreophers. Paris: Dis Voir.

Molesworth H. (20I I). Dance / Draw. Boston: Hatje Cantz.

Peressini G. (2020). Design e tecnologie digitali per la danza. Dispositivi di progettazione coreografica del movimento. Tesi di dottorato di ricerca in Scienze del design, Scuola di dottorato in Architettura, città e design. Tutor prof. M. Ciammaichella. Università luav di Venezia.

Pierce K. (1998). Dance Notation Systems in Late I7th-Century France. In Early Music, vol. 26, n. 2, 1998, pp. $286-299$.

Pontremoli A. (2006). La danza. Storia, teoria, estetica nel Novecento. Roma-Bari: Laterza.

Saint-Léon A. (1852). La Sténochoréographie, ou Art d'écrire promptement la Danse avec portraits et biographies des plus célèbres Maitres de Ballets ancient et modernes; par Arthur Saint-Léon, ler maitre de ballets, \& ler Danseur de L'Opéra. Paris: Imprimerie de Moquet.

Tomlinson K. (1735). The Art of Dancing. Explained by Reading and Figures: Whereby the Manner of Performing the Steps is Made Easy By a New and Familiar Method: Being the Original Work. First design'd in the Year 1 724, and now Published by Kellom Tomlinson, Dancing-Master. In Two Books. London: Printed for the Author.

Tufte E. R. (1990). Envisioning information. Cheshire: Graphics Press.

Zorn F. A. ( I 887) Grammatik der Tanzkunst theoretischer und praktischer Unterricht in der Tanzkunst und Tanzschreibkunst oder Choregraphie. Leipzig: J.J.Weber.

\section{Author}

Massimiliano Ciammaichella, Università luav di Venezia, massimiliano.ciammaichella@iuav.it

To cite this chapter: Ciammaichella Massimiliano (2021). Il disegno della danza. Notazione e controllo dello spazio performativo/Drawing of the Dance. Notation and performative space control. In Arena A., Arena M., Mediati D., Raffa P. (a cura di). Connettere. Un disegno per annodare e tessere. Linguaggi Distanze Tecnologie. Atti del $42^{\circ}$ Convegno Internazionale dei Docenti delle Discipline della Rappresentazione/Connecting. Drawing for weaving relationship. Languages Distances Technologies. Proceedings of the 42th International Conference of Representation Disciplines Teachers. Milano: FrancoAngeli, pp. |47|-|488 